\title{
Tort Reform and Access to Justice: How Legal Environments Shape Lawyers' Case Selection
}

\author{
Mary Nell Trautner
}

Published online: 14 September 2011

(C) Springer Science+Business Media, LLC 2011

\begin{abstract}
How do lawyers decide which cases to accept? Previous studies suggest that they use a simple risk/return formula to make such decisions. I argue, however, that legal environments also shape lawyers' decisions. Analyses of in-depth interviews with lawyers across four states demonstrate that lawyers make different decisions about cases in different legal environments. Lawyers in states without tort reform emphasize the importance of how "likeable" a client may be to a potential jury, whereas lawyers in states with tort reform instead focus on the defendant's "liability." These differences have important implications for who has access to the civil justice system, and for consumer and medical protections more generally.
\end{abstract}

Keywords Legal profession · Access to justice $\cdot$ Decision making $\cdot$ Legal environments

Plaintiffs' lawyers have a great deal of discretion in deciding which cases to accept and which clients to represent. Because people injured by defective products or medical errors almost always need a lawyer in order to obtain compensation in the civil justice system, lawyers' decisions determine who has the opportunity to be compensated for their injuries. (Kritzer 2004; Martin and Daniels 1997; Michelson 2006; Sandefur 2008). In short, lawyers act as gatekeepers to justice in civil courts.

But personal injury lawsuits do much more than simply compensate victims. Historically, they have played a key role in bringing to light dangers and risks that have gone unnoticed by regulators and the criminal courts - including, for example, the harms posed by exposure to asbestos, silicone breast implants, or faulty tires. As a result, personal injury litigation has benefitted not only the plaintiffs of a particular case, but also the general public by punishing and guarding against unsafe products, workplace hazards, and preventable medical errors (Abel 1987; Koenig and Rustad 2001). Personal injury litigation, in other words, can act not only as a means of compensating victims, but also as a deterrent to unsafe or risky behavior by encouraging self-regulation among doctors and corporations (Abel 1987; Bogus 2001; Granfield 2001), as well as a method of expanding consumer rights and improving public

M. N. Trautner $(\bowtie)$

University at Buffalo, SUNY, Buffalo, NY, USA

e-mail: trautner@buffalo.edu 
safety (Burke 2002). Indeed, many of the safety laws we now take for granted, such as seatbelts, pharmaceutical drug tests, warning labels, and machine guards, are the result of personal injury lawsuits. Thus, the decisions that lawyers make about which cases to accept and which to decline can have far-reaching consequences.

It is not always immediately obvious to lawyers which cases are worth pursuing, however. While the plaintiff's injuries are often apparent at the outset, the underlying facts of the case are frequently unclear and require extensive investigation. Previous research suggests that personal injury lawyers select cases based on a relatively simple risk/return formula in which lawyers pursue cases that offer potentially high returns with few risks and decline cases with either low returns or high risks (Kritzer 2004; Kritzer and Krishnan 1999). This assessment is necessary, scholars point out, because lawyers work on a contingency basis, which means they are only paid and reimbursed for their expenses if they win a case. And if they do not win, not only are they not paid but they must also bear any costs associated with the case.

This emphasis on monetary risks and returns, however, is de-contextualized, and thus obscures how legal environments and local cultures also shape the decisions that lawyers make about which cases to accept. In this article, I show how context matters for legal decision making. My analyses, based on in-depth interviews with lawyers in two different legal settings across four states, demonstrate that lawyers make different decisions depending on the legal environment in which they are embedded.

\section{Legal Decision Making in Context}

Plaintiffs' personal injury lawyers have always been selective in the cases they pursue (Crane 1988; Daniels and Martin 2000; Kritzer 1996, 1997a, b; Parikh 2001). Indeed, because they work on a contingency basis, lawyers must be careful about which cases they accept. Nearly all the previous findings on lawyers' selection of cases suggest that lawyers make decisions according to a risk/return formula, following the rational choice model set forth by neoclassical economics (Kritzer and Krishnan 1999). In this approach, the probabilities of winning a case and its likely payoff are calculated and compared to the time it will take to prepare the case and shepherd it through either settlement or trial verdict. According to this formula, lawyers pursue cases with low risks (a high probability of success) and high returns, and they reject all other cases (including those with high risks and low returns, low risks and low returns, and high risks and high returns) (Kritzer 1996, 1997a, 2004; Parikh 2001).

Rational choice explanations for decision making are often critiqued for their decontextualization. Sociologists have argued that decision makers in other contexts are embedded in a dynamic web of social relationships, cultural expectations, and social structure (e.g., Granovetter 1985; Krippner and Alvarez 2007; Pescosolido 1992; Zukin and Dimaggio 1990). That is, actors do not make decisions in isolation from their wider environments and interactions with others; their behavior, including economic and decision making behaviors, are influenced by social norms, social values, and social structure. Yet, this sociological lens has not yet been used to expand our understanding of lawyers' decision-making. Doing so raises new and important questions about how social context-including local legal environments - affects lawyers' decisions about which cases to accept and which to reject.

Among socio-legal scholars, it is widely accepted that social environments shape how people think about law and how they apply law to legal and non-legal problems (e.g., Ewick and Silbey 1998). Scholars in this field often examine "legal environments," which includes both the written laws "on the books" as well as the law "in people's heads" 
(Kritzer and Zemans 1993; LoPucki 1996; Sarat 1977; Sullivan et al. 1994), referring to people's interpretations of law, attitudes towards law and lawyers, and social norms surrounding law. Studying both aspects of legal environments is important because, as LoPucki demonstrated, even in communities with the same written laws there can be "persistent, systematic differences in legal outcomes" $(1996,1502)$ due to differences in interpretation, expectations, social norms, and attitudes. In fact, this is one of the central findings in the sociology of law: The interpretation of law by legal and non-legal actors can have profound implications for both the making of law and legal outcomes (see, for example, Edelman 1990, 1992; Edelman and Suchman 1997, 1999; Engel 1984; Sutton et al. 1994). In other words, while written laws shape what is legally viable, it is the law "in people's heads" that shapes how law is applied and carried out. Thus, how lawyers interpret such things as legal doctrine and community standards are just as important as the written law in shaping decision making. I argue that this is also true of how personal injury lawyers evaluate potential cases.

The legal environments in which personal injury lawyers work have seen profound changes to both the law "on the books" and the law "in people's heads." In particular, states which have experienced tort reform have seen extensive changes to the laws on the books, including restrictions on the amount of money that can be recovered for injuries, the types of products and organizations that can be sued for wrongdoing, and increased qualifications for expert witnesses (see ATRA 2004). Tort reform has affected the law "in people's heads" as well. For example, media campaigns that typically accompany tort reform warn about the consequences of "frivolous lawsuits" on health care, business, and American free enterprise (see ATRA 2003; Haltom and McCann 2004; Huber 1990; Olson 1991).

As a result, many studies find that tort reform has had far-reaching consequences. For example, some studies find that tort reform depresses the number of lawsuits filed by lawyers (Daniels and Martin 2000; Finley 1997; Kessler and McClellan 1996; Sharkey 2005). Other scholars have noted that when states impose caps on noneconomic damages, that people with no (or low) economic losses are much less likely to bring a case because their potential reward is limited (e.g., Carroll et al. 2004; Finley 1997, 2004; Koenig and Rustad 2001; Lofquist 2002; Martin and Daniels 1997; Swartz 2005). Researchers have also found that many personal injury lawyers, in response to tort reform, have closed their practices entirely, or shifted into different legal specializations (Daniels and Martin 2004). What's more, studies find that the media campaigns that accompany tort reform can affect jurors' decisions (Greene 1990; Haltom and McCann 2004; Loftus 1979). Loftus (1979), for example, found that even a single exposure to anti-lawsuit advertising substantially lowered the monetary award that jurors were willing to give in personal injury cases. Thus, lawyers in states with heavy advertising and media campaigns in support of tort reform must contend not only with changes to black-letter law, but also with changes in jurors' attitudes towards these types of cases.

Yet, even as scholars in sociology have recognized the importance of environment to individual decision making, and even as socio-legal scholars have documented the many effects of tort reform on personal injury practice, scholars have not yet examined how such changes in legal environment affect lawyers' decisions to accept or reject a case. Indeed, previous studies of lawyers' case selection precluded questions of legal context by examining lawyers in only one city or state (Daniels and Martin 1999, 2000, 2001; Kritzer 2004; Parikh 2001; Van Hoy 1999). In this article, I seek to expand our understanding of lawyers' decision making by employing a comparative research design to examine how legal environments shape the decisions that lawyers make. While I find that lawyers continue to make risk assessments when deciding which cases to accept or reject, the 
equation they use in making such assessments varies dramatically based on their local legal environment. I begin with a discussion of my data and methods, then turn to my findings, which demonstrate striking differences in how lawyers in states with tort reform and states without tort reform evaluate potential cases. I close with a discussion of the implications of these findings for social justice.

\section{Data and Methods}

I focus my analysis on lawyers who handle products liability and/or medical malpractice cases. This focus offers a unique opportunity to understand how legal environments shape lawyer decision making for two reasons. First, although products liability and medical malpractice cases account for fewer than $20 \%$ of all personal injury trials (Cohen and Smith 2004), they are generally the primary target of state-level changes to tort law, including limits on pain and suffering awards, caps on punitive damages, changes to joint and several liability, and strict requirements for expert witnesses (Baker 2005; Koenig and Rustad 2001; Zegart 2004). Second, no other specialties of personal injury law have received as much media attention or occupy such a prominent spot in the public consciousness (Haltom and McCann 2004; Lofquist 2002; Vidmar 1998). The majority of high-profile personal injury cases, for example, are medical malpractice or products liability cases (e.g., the McDonald's hot coffee case, or prescription drug cases like Fen-Phen or Vioxx). Tort reform organizations often incorporate such cases into their campaigns as examples of "frivolous lawsuits," and use them to warn about the dangers such lawsuits pose to the availability of health services. Thus, lawyers working in locations hit by intense tort reform campaigns must contend not only with changes in black-letter law, but also with jurors' attitudes and expectations of these sorts of cases.

In order to examine how legal environments affect lawyers' decision-making, I interviewed lawyers from four states who work in two very different contexts. First, I interviewed 42 lawyers in two states - Colorado and Texas - which have experienced extensive changes to tort law (including caps on noneconomic damages, which limits the amount of money someone can receive for pain and suffering, emotional anguish, disfigurement, or loss of enjoyment) (see Dobbs 2000). In fact, according to the American Tort Reform Association (ATRA 2004), Colorado has passed more tort reforms, in more issue areas than any other state, and Texas ranks second. I refer to these states as "reform states." In addition, both Colorado and Texas experienced heavy media campaigns in support of tort reform. These campaigns typically paint doctors, corporations, and insurance companies as the victims of frivolous lawsuits, greedy lawyers, and a tort system "out of control" (see Haltom and McCann 2004). In both Colorado and Texas, such media campaigns told people that, as consumers, they pay the "ultimate price" for lawsuit "abuse" through higher prices on insurance premiums and retail goods, and reduced access to doctors and healthcare providers. For example, a direct mail advertisement sent to all Texas voters in 2003 read:

Dear Susie, I regret to inform you that due to increasing junk lawsuits and medical insurance costs, I will permanently close my practice on September 1st. I attended medical school to care for local families, not to defend against frivolous lawsuits and the increasing costs of medical practice. It has been an honor caring for you and your family. Sincerely, Your Family Doctor

The reverse side of the advertisement encouraged Texas voters to "save your family doctor" by voting in favor of tort reform. In addition, many Texas voters also saw traveling billboards that provocatively asked, "Are you ready to kiss your healthcare goodbye?" 
Second, I also interviewed 41 lawyers in two states - Massachusetts and Pennsylvaniawhich, according to newspaper searches and conversations with local Trial Lawyers' Association representatives, did not pass any major tort reforms or experience heavy media campaigns calling for changes to tort law (see also Avraham 2006). I refer to these as "nonreform states." Massachusetts and Pennsylvania are considered by both plaintiff and defense attorneys to be more friendly toward plaintiffs than to corporations (Boynton 1999; Harris Interactive 2004). Philadelphia is one of only thirteen cities or regions in the U.S. named as a "judicial hellhole" by the American Tort Reform Association (ATRA) and its members (ATRA 2003), and, along with Boston, is listed as one of the 25 local jurisdictions with the "least fair and reasonable litigation environments" by a poll of corporate attorneys (Harris Interactive 2004). In addition, Massachusetts and Pennsylvania have each passed very few, small-scope tort reform measures. ${ }^{1}$

To minimize intra-state variation, I selected lawyers from a single large city in each of the four states (Denver, San Antonio, Boston, and Philadelphia). ${ }^{2}$ I then selected products liability and medical malpractice specialists in those four cities based on recommendations from each state's local Trial Lawyers Association, ${ }^{3}$ as well as from online legal directories (such as Martindale-Hubbell and FindLaw.com ${ }^{4}$ ) and other lawyers I interviewed. I contacted 116 lawyers and interviewed 83 , for an overall response rate of $72 \%{ }^{5}$ My sample includes 14 women $(17 \%)$ and $69(83 \%)$ men; $5(6 \%)$ racial/ethnic minorities; and 15 (18\%) solo practitioners. These characteristics resemble characteristics of personal injury lawyers as a whole (for example, the Association of Trial Lawyers in America, as reported in Hayes 2005, is composed of $13 \%$ women and $4 \%$ minorities). Table 1 shows the distribution of personal and professional characteristics between reform and non-reform states.

Interviews took place in the spring of 2005, just two years after voters in Texas and Colorado approved significant tort reform measures, including caps on non-economic damages in medical malpractice cases. Interview questions were intended to capture lawyers' practices, decision-making processes, attitudes, and beliefs about case selection, juries, tort reform, and local legal cultures. I asked lawyers to walk me through a typical first meeting with a client, to share the characteristics of injuries, clients, and defendants that influence their evaluation of cases, what sorts of factors they believe juries respond to, and how their practices have or have not changed over time. I also asked them to speculate

\footnotetext{
${ }^{1}$ Massachusetts has passed a small-scope modified rule of joint and several liability which applies only to public accountants, and has modified attorney's fees in medical malpractice cases (40\% of the first $\$ 150,000$ recovered, $33.3 \%$ of the next $\$ 150,000$ recovered, $30 \%$ of the next $\$ 200,000$ recovered, and $25 \%$ of any amount over $\$ 500,000$ recovered). Pennsylvania has passed just two reforms: a similarly small scope joint and several liability rule and a venue change for medical malpractice cases (all cases must be filed in the county where the malpractice occurred).

2 Trial Lawyers' Associations (TLAs) are professional membership organizations for lawyers representing plaintiffs (although some lawyers representing defendants sometimes also join). At either the city, state, regional, or national level, these associations provide information for their members (such as information exchange groups, presentation tips, etc.), provide continuing legal education (CLE) courses tailored for plaintiffs lawyers, and lobby on behalf of trial lawyers to local, state, and federal legislatures.

${ }^{3}$ I chose the largest city in each state (Philadelphia, Denver, Boston), with the exception of Texas, in which I selected the second-largest city (San Antonio). Houston, the largest city, has a reputation among lawyers and political organizations as being an especially plaintiff-friendly jurisdiction, while San Antonio does not, thus making San Antonio more representative of the state's overall legal environment (Kasindorf 2004; Tooher 2005; see ATRA 2003 on jurisdictions surrounding the city of Houston).

${ }^{4}$ http://www.martindale.com/; http://www.findlaw.com/

${ }^{5}$ This project was reviewed and approved by the Human Subjects Committee (Institutional Review Board) at The University of Arizona. In addition, I also obtained a Confidentiality Certificate (CC) from the U.S. Department of Health and Human Services (DHHS).
} 
Table 1 Sample characteristics

Reform states Non-reform states Total

(San Antonio and Denver) (Boston and Philadelphia)

\begin{tabular}{lccc}
\hline Men & $33(79 \%)$ & $36(88 \%)$ & $69(83 \%)$ \\
Women & $9(21 \%)$ & $5(12 \%)$ & $14(17 \%)$ \\
Racial/Ethnic Minorities & $3(7 \%)$ & $2(5 \%)$ & $5(6 \%)$ \\
Solo Practitioners & $10(24 \%)$ & $5(12 \%)$ & $15(18 \%)$ \\
Average Years of Experience (range) & $23.5(7-38)$ & $23.3(8-37)$ & $23.5(7-38)$ \\
\hline
\end{tabular}

as to how they would respond to a variety of scenarios, including whether they would accept a strong case from a "weak" client, or a weak case from a "strong" client. The interviews were taped, and ranged from 45 minutes to more than three hours, with most lasting approximately one hour and 15 minutes.

Along with a small team of student research assistants, I transcribed all the interviews, then coded and analyzed the transcriptions using standard grounded theory methodological techniques. According to this technique, I read through each interview several times, noting recurring themes. From this, I developed thematic categories and codes related to lawyers' decision making process and their discussion of their local legal environment, placing each lawyer's response into one or more of the thematic categories, which were then further divided into smaller sub-groups. I then examined all of the lawyers' responses in each subgroup, looking for similarities as well as differences, especially as they related to lawyers' decisions about cases and clients. Once each subgroup was formed and analyzed, I moved on to the next subgroup, noting its placement within the larger thematic category. This process was repeated until the analysis was complete.

\section{Tort Reform and Lawyers' Case Selection}

Personal injury lawyers in both reform and non-reform states take into consideration the same three factors when making decisions about whether to accept a new case: (1) the monetary value of the injury ("damages"); (2) the factual components of a case, including their assessment of their ability to demonstrate wrongdoing or negligence on the part of a doctor or product manufacturer ("liability"); and (3) their estimation of how the potential client will be evaluated by a jury ("likeability"). Across cases, each of these categories can vary dramatically: damages can be significant or trivial; liability can be clear, difficult to prove, or even nonexistent; and lawyers can decide that clients will be perceived as "likeable" or "unlikeable" by a jury.

The qualities that make a client likeable or unlikeable to a jury, many lawyers told me, are "the same things that make us likeable or unlikeable in everyday life," as one Boston lawyer said. As a Philadelphia lawyer elaborates,

It's the same characteristics that cause people to be appealing to us in our everyday lives. You know, when you sit down and you meet somebody that seems to be centered and has a good sense of humor and they're honest and forthright and all those characteristics that we would all find appealing if you meet someone in the street, or the bar, or wherever you socialize, are the kinds of things that make clients attractive as litigants. 
Most lawyers also mentioned honesty and credibility in particular as important qualities that contribute to making someone likeable. Thus, most lawyers explicitly attribute likeability to personality traits.

But likeability may also have something to do with status characteristics like race, social class, appearance, and employment status. For example, several Philadelphia lawyers revealed that a large number of their clients were African-American, or low wage earners. In Philadelphia, those are likeable clients because there is a good chance that the jury will be composed of AfricanAmericans or low wage earners, and "juries identify with clients that are like them," as one Philadelphia lawyer said. He continued, "Black juries usually give for black clients." Another Philadelphia lawyer agreed, saying, "Race matters in the city. A black kid I'm representing ... is going to get a fair shake here." But in Colorado, or in Texas, such clients might not be deemed so likeable. For example, one San Antonio lawyer said, "I find that generally, the prettier and whiter my clients are, the less likely their case goes to trial. The poorer and less sophisticated my clients are, a little bit higher risk of going to trial. Same thing [with values], the more sophisticated, prettier you are, higher value. The poorer you are, less well spoken, smaller values." For many of these lawyers, the ideal outcome is to settle out of court because going to trial involves unknown outcomes. Thus, when this lawyer says that "pretty" and "white" clients are less likely to go to trial, he is saying that they generally have more optimal outcomes.

The "likeability" of social and demographic characteristics is not uniform across states or jurisdictions. It is not the case that minorities and the poor, for example, are uniformly deemed unlikeable. The more important consideration, lawyers agreed, is the extent to which a client's characteristics reflect the composition of the jury pool, or the community at large. Lawyers want a jury to be able to identify with and relate to their client. As a Boston lawyer said, "I think juries respond very positively to a person who they can relate to." A Philadelphia lawyer elaborates:

Clients that will be identified with by the jury pool that you're gonna try the case to are certainly helpful. If you're trying the case in Philadelphia, most of the people are working class people, and if you have a working class person who got hurt, and they were struggling and doing the best they can, a man or a woman with three kids and they got up everyday and went to work and now they're not getting up and going to work anymore, that's a good client to have in the particular jurisdiction that you're in, so that's a characteristic I look for.

A "perfect" personal injury case, then, would have unquestionably significant damages, strong and clear liability, and a "likeable" client. However, lawyers rarely encounter such a case. As one San Antonio lawyer said, "I've never had a case that doesn't have warts, that doesn't have something [wrong with it]." And in Philadelphia, a similar statement: "How many times are you going to have a great client with great liability? Those are the best cases, those are the cream of the crop; you don't get them a lot. There's always something wrong with the cases." As a result, lawyers must make decisions about how to balance, or weigh, each of these components. These decisions, my data show, are influenced by the social, political, and legal environments in which lawyers practice. Lawyers in reform states tend to make very different decisions about which cases to accept than do lawyers in nonreform states, even as they rely on the same three factors in making these decisions.

Because the financial costs associated with medical malpractice and products liability cases are very high (often requiring lawyers to invest $\$ 50,000-\$ 100,000$ or more), my findings show that damages are the most important factor for lawyers in both types of states. For all personal injury lawyers, a case must have the potential to recover significantly more money than he or she will be required to invest. There are no set 
monetary thresholds: They vary from lawyer to lawyer and firm to firm, and depend on the type of case and what would be required in terms of product testing or expert witnesses. However, in general lawyers are looking for a sizable recovery for both themselves and the client once expenses are covered. As one Philadelphia lawyer put it, "If there's not a potentially viable recovery at the end of the day, it doesn't make a whole lot of sense." Therefore, cases not meeting their thresholds for potential damages are not accepted by lawyers in either reform or non-reform states. "I turn down clearly meritorious cases all the time because I think they're just not worth enough money," another Philadelphia lawyer told me, echoing the sentiments of most lawyers interviewed. Thus, tort reform has generally not affected this aspect of the decision making process: Lawyers' assessment of damages remains the most important factor in their decisions to accept or reject a case.

However, while significant damages are a necessary precondition for case acceptance, they are not sufficient. All of the lawyers in my sample agreed that a case needed to have more than just potentially significant damages to make it worth accepting. Their estimations of the other components of a case - liability and likeability - then become crucial to their decision about whether to take on a case. My research shows that lawyers weigh these two factors very differently according to their legal environment. Lawyers in non-reform states (Pennsylvania and Massachusetts) generally assign the most weight to the "likeability" of the potential client. Lawyers in reform states (Texas and Colorado), however, emphasize "liability": how egregious the negligence was, and how easily it can be proven.

\section{Case Selection in Non-Reform States}

In deciding what cases to accept, lawyers in non-reform states indicated that once the damages threshold has been met they generally assign the most weight to the client's "likeability." Indeed, these lawyers stressed that the client was one of, if not the most, important components of a case. "If you have a very likeable client," one lawyer in Boston told me, "you're halfway there." These lawyers argued that a case really came down to how the jury perceived their client. "The most important thing...in any plaintiff's practice is the plaintiff himself," another Boston lawyer told me. "If he or she is going to be a good witness, then you're probably going to have a good case," he continued. In fact, a number of lawyers suggested that "likeable" clients can make up for the other elements of a case that may be missing or weak. As another Boston lawyer said, "Sometimes the facts of the case become irrelevant compared to who the client is, what their life is like." In other words, in non-reform states, lawyers believed that the odds of winning a case would rely heavily on how the jury perceived the client: juries would give money to people they liked, and would not give money to people they did not like. This belief was summarized by a Philadelphia lawyer:

If the clients are really good, I know they're good, I like them, but not enough evidence pops up...I'd probably take that case...because the case is easier to be received by the jury if they like the people. They're more willing to give the benefit of the doubt if the client is real likeable.

A Boston lawyer further emphasizes the importance of likeability in the eyes of a jury:

[A case is all about] who's going to get the money. If the people that are going to get the money are nice, sympathetic, make a nice appearance, [and] are nice people, that can carry a case that is not quite as good. I had another case that on paper it looks great and you hate the people. Well everybody else is going to hate the people, too. So that case goes down and crashes and burns. 
For these and other lawyers in the non-reform states, a client's "likeability" is the most important component of a case, and can even make up for other aspects of a case that may not be as strong. In fact, when asked whether they would accept a case with uncertain liability from a "likeable" client, $85 \%(n=35)$ of the 41 lawyers in non-reform states said that they would accept such a case.

By the same token, these lawyers' belief in the importance of a client's "likeability" leads them to reject cases from "unlikeable" clients, even if the other elements of a case are very good. In fact, $61 \%$ of the lawyers $(n=25)$ in non-reform states said they would reject such a case. Without a good client, these lawyers believe, a case has little chance of success. As a Boston lawyer explains,

You could have the best case in the world. The doctor could have operated on you and left his scalpel in you. But if you have not paid your taxes, if you have not treated your children well, if you have a criminal history, the jury's just not going to like you. So you may get liability and then they will suck down your damages until it's not worth pursuing the case. So personality and trustworthiness and likeableness of the person [are] extremely important right from the start.

In short, these lawyers believe that juries make their decisions about monetary awards largely based on how well they like the plaintiff. And if the plaintiff is not deemed "likeable," lawyers believe the juries will either find in favor of the defendant or make only a very small award to the plaintiff - in both instances making it a financially unfeasible case for the lawyer. Thus, in non-reform states, although "likeable" clients can make up for weaker aspects of a personal injury case, including unclear liability, the reverse is not true: clear liability generally cannot make up for an "unlikeable" client. As a result, in nonreform states, it seems that people who are considered "likeable," however that is defined at the local level, are more likely to be afforded access to the civil justice system than those deemed "unlikeable." This is of crucial importance, particularly because social inequalities may be implicated in one's perceived "likeability."

Evaluating cases based on personal and status characteristics of clients is certainly not unique to personal injury cases. Socio-legal research in criminal cases, for example, describes how public defenders rely on a potential client's appearance, race, age, demeanor, and style of talk to understand the events which led to the client's arrest (Sudnow 1965). Similarly, Frohmann (1991, 1997) and Stanko (1981-82) find that criminal prosecutors decide which cases to file in part by relying on stereotypical characteristics of victims and defendants to determine credibility (of the victim) and convictability (of the defendant). Prosecutors want to file and move forward on cases they believe will win in front of a judge or jury. Thus, the credibility of the victim is key. "Solid" cases are in part determined by a victim's appearance, character, employment status, gender, race, and age. As Stanko (1981-82) writes,

A pleasant appearance, residence in a good neighborhood, a respectable job or occupation, lack of nervous mannerisms, and an ability to articulate clearly, are decided advantages. Inferences that a victim might be a prostitute or pimp, a homosexual, or an alcoholic, on the other hand, may seriously damage a victim's credibility. All of these factors must be carefully weighed. (230)

Thus, much like the personal injury lawyers in non-reform states, lawyers in the criminal realm draw on "common sense" and stereotypical characteristics of victims when deciding which cases to prosecute. Cases from "stand up" and "solid" victims move forward, while others do not. My findings offer support for this - but only in the non-reform states. 


\section{Case Selection in Reform States}

Lawyers in reform states - Texas and Colorado - emphasize the importance of liability, that is, the extent of the wrong-doing and how clearly it can be proven, instead of emphasizing the importance of a client's perceived "likeability," as did lawyers in non-reform states. Thus, for lawyers in reform states, winnable cases are those that have significant damages and clear evidence of wrong-doing, regardless of a client's "likeability." Whereas only 39\% of non-reform lawyers said they would accept a case with clear liability but an unlikeable client, $75 \%$ of lawyers in reform states said they would accept such a case. Good cases, for lawyers in reform states, are those that have strong facts, even if that means representing an "unlikeable" client. As one San Antonio lawyer said, "If...you've got a crappy client, the case may not be as good, but at least you still have a case." Lawyers in reform states felt that a client's weaknesses would be overshadowed by clear liability, but that the reverse was not true: a weak liability case could not be overcome by a strong client. As one Denver lawyer explained,

I don't care how likeable the person is, because juries don't like plaintiffs anyway, and so a likeable plaintiff is not going to carry a weak case. A strong case is much more likely to carry a less likeable client. You can't go in with a weak case.

As a result, the majority of reform state lawyers $(62 \%, n=26)$ declined cases with uncertain liability, even if they had a highly "likeable" client. "I wouldn't take a less-thangreat case," one Colorado lawyer emphatically stated, "even if I had Mother Teresa as my client." The difference between the reform and non-reform state lawyers is remarkable: In reform states, lawyers are less likely to consider a client's "likeability" in their decision making process; it is simply not what makes a "great case" upon their initial evaluation. This is in sharp contrast to lawyers in non-reform states, who routinely accept cases with unclear liability, as long as they perceive the client to be "likeable" by juries.

Many lawyers in reform states recalled that prior to tort reform, they screened cases in much the same way as do lawyers in non-reform states. "It has changed with the new laws," said a San Antonio lawyer. As a Denver lawyer further explained, "We used to think that [presenting the victim's side of the story] was great for us because it told jurors what great people our plaintiffs were." But that strategy changed, he went on to say, as a result of the aggressive media campaigns that painted such clients as greedy and manipulative. "Jurors seem to not want to compensate people who are hurt real bad," one San Antonio lawyer said. "They think that the person who's got the lawsuit filed against them is the victim, rather than the person who didn't do anything wrong."

As a result of such campaigns, lawyers in reform states believe that juries tend to be more sympathetic towards defendants and not the plaintiffs in personal injury cases - that is, the doctors accused of negligence or the company accused of poor product design rather than the injured patient or consumer. Jurors, lawyers in reform states believe, do not want to "reward" people who file lawsuits with positive verdicts, but rather, want to "punish" them for eroding the "fabric of society," as claimed in many tort reform media campaigns (see such claims as made by Huber 1990; Olson 1991). Lawyers strongly believe these campaigns have had profound impacts on jurors, as these two San Antonio lawyers argue:

The insurance companies and all the medical organizations...had an overwhelming amount of, just staggering amounts of advertising, constant commercials about this poor doctor, as he walks down the stairs, locks the door to his office and there's all these poor, impoverished kids crying because they have no doctor. "And pretty soon, 
they'll be no more doctors in this state. And then where will you go?" They ran so many of those that, I think it was just beating the public's head. And so now, they're so ingrained now that everyone thinks all your doctors are going out of business and we've got to save them and we can't punish them.

I think there's a perception, because insurance companies have spent so much money trying to change the reality, that people perceive that all lawsuits are frivolous. I think they perceive that. And so we have to prove up front that this case is valid, and we waste a lot of time talking about frivolous lawsuits and things like that....And juries tend to be sympathetic to the defendant, I think, more so than the injured party, whereas 20 years ago that was different.

Lawyers believe that not only have the heavy advertising campaigns influenced jurors to be sympathetic to defendants and hostile to plaintiffs, but jurors also fear that if they award money to plaintiffs their insurance rates will increase, their doctors will leave, or their civic organizations will dry up and disappear. Lawyers' perceptions that such media campaigns have a real impact on jurors are supported by empirical research. Previous studies (e.g., Greene 1990; Loftus 1979) demonstrate that jurors' decisions are indeed influenced by media sources, including newspaper reports, radio and television news, advertising, movies, and televised crime shows and courtroom scenes. Loftus (1979), for example, found that even a single exposure to anti-lawsuit advertising substantially lowered the monetary award that jurors in personal injury cases were willing to give. As a result, lawyers believe they have to prove that their case is not "frivolous" and that the defendant really did do something wrong, which is why reform state lawyers emphasize the importance of liability rather than likeability when evaluating cases.

In short, lawyers in reform states believe that "jurors have changed the way they look at things" because of the media campaigns surrounding tort reform, as one Denver lawyer said. And, as a result, these lawyers have changed their own evaluations of cases, emphasizing proof of wrong-doing over the perceived "likeability" of a client.

Once a case has been accepted, lawyers then work to improve their odds of winning by trying to turn an "unlikeable" client into a "likeable" client. "Bad" clients, they reason, can be "fixed", or "cleaned up," or "coached" into looking and sounding like people that jurors will respond to in a positive manner. Most of the lawyers who accepted cases from unlikeable clients agreed, as a San Antonio lawyer put it, that "there are ways to soften a client who might not make a great impression." Lawyers talked about having clients change their clothing, cut their hair, or cover up tattoos. Others try to get their case settled without the defense or jury ever seeing or interacting with their client. As another San Antonio lawyer says: "I can make some money on this case, but I've got to make sure that the other side never gets to see this person."

While it is not what drives their decisions to accept or not accept cases, reform-state lawyers understand that likeability impacts the ultimate value of the case, which is a large part of why they try so hard to "clean up" or "hide" their "unlikeable" clients. Their hope is that juries will overlook their clients' likeability flaws if the damages of a case are big enough or if the liability is strong enough. However, many find that this is not always what happens, and that their strategies to "clean up" or "hide" the client often do not work. As one San Antonio lawyer put it, "People on juries tend to want perfection of the people on trial," just as they want perfection in liability, or the facts of the case.

Repeatedly, lawyers spoke of cases where they got "burned" or "poured out" because a jury did not like their client. The jury is tough on their clients, and still judge the plaintiffs just as harshly-if not more so- than they do in the non-reform states. The following San 
Antonio lawyer explains that he, like many others in town, are so "desperate" for good cases, that he takes risks on unlikeable clients, even when he knows that he should not:

Obviously juries reward people they like, and they don't reward people they don't like. So if the guy's a jackass, and it shows right away, you should not take their case. That is the rule all attorneys should operate by, but you don't operate that way. They've got \$250,000 in medical bills and you say, "You know what, I can overcome this. I can prep him, I can work with him, I can make him more presentable to the jury, or her, make her not seem so bitchy." .... And it never works. It never works! If they come across as whiny, as complaining, no matter how bad [the injuries are], the juries don't like them, so they're not going to give them much.... If you're being smart, you won't take their case. But as you start to get desperate, and as things become harder, you start to make bad decisions. You know, you start to take a chance. "Well, this guy does have $\$ 250,000$ in medical bills." And you start to take chances that you shouldn't have and you eventually get burned. And so, that's what I've found myself doing. Taking chances I should not have taken....Cases where the guy has serious problems I should not take his case, but because his injuries are so massive, I take a chance and I get burned.

Thus, many of the cases that lawyers bring into the system post-reform are risky in terms of likeability, cases that lawyers would have screened out before the passage of tort reform, just as they still get screened out in the non-reform states. Because they believe that "juries don't like plaintiffs anyway," lawyers feel pressure to focus on damages and liability, and they sometimes "fool" themselves, as one lawyer put it, into thinking that jurors will overlook the faults of the client, when in fact, they often do not. In other words, lawyers themselves worry that they are often making the wrong decision when evaluating cases, as they try to adapt their decision making process to a new legal culture. As this lawyer demonstrates, likeability is not irrelevant to reform states. However, it is not, for most lawyers, the primary factor they consider when making decisions about cases. The tendency to focus first on liability in reform states, and likeability in non-reform states, is clear.

In sum, my findings show that differences in legal environments lead to differences in how lawyers make decisions about which cases to accept and which to reject. Lawyers in states without tort reform emphasize the importance of how "likeable" a client may be to a potential jury, whereas lawyers in reform states generally are more likely to focus first on the clarity of evidence of wrongdoing, or the defendant's "liability." This is not to say that reform state lawyers never think about likeability or that non-reform states never consider liability. Rather, tort reform influences which of these two factors play the most prominent role in the majority of lawyers' decision making process. The consequences of this difference, I argue, are not uniformly positive or negative, and have significant implications for who has access to the legal system.

\section{Discussion and Conclusion}

If social context made no difference, lawyers across the four states would evaluate potential cases in similar ways. Yet I have shown that socio-legal environments do shape lawyers' decisions about cases and clients. When evaluating cases, lawyers in non-reform states emphasize the "likeability" of the potential plaintiff-that is, whether juries will respond positively to their client. Lawyers in reform states, by contrast, emphasize evidence of the defendant's wrong-doing, or liability. The issue of 
who has access to the civil justice system is a key implication of this finding. Without a lawyer, a person has little chance of successfully suing a doctor, hospital, or product manufacturer when they have been harmed by a medical error or defective product. Lawyers thus act as gatekeepers, and their evaluation of a case determines who gains access to the civil justice system and who does not.

Previous research has shown that tort reform effectively closes the courthouse door to certain populations, including the elderly, housewives, and families of dead children (e.g., Carroll et al. 2004; Finley 1997, 2004; Koenig and Rustad 2001; Lofquist 2002; Martin and Daniels 1997; Swartz 2005). This is because their cases rely almost exclusively on noneconomic damages (i.e., pain and suffering), which are capped at a certain dollar amount in tort reform states, making these cases less economically valuable. Yet, my findings suggest that, in some cases at least, tort reform may also open the courthouse door. By no longer emphasizing the importance of a client's "likeability," lawyers in reform states are accepting cases from new groups of people: clients whose cases might be rejected in non-reform states because of their perceived "unlikeability" to a jury.

Who are these "unlikeable" clients? Most often, lawyers described them as people with brusque personalities or questionable credibility. But implicit in lawyers' descriptions (and, at times, explicit) was that a client's status characteristics - such as race, class, employment status, or even appearance - could affect their "likeability" to a jury. Thus, a client who is unemployed or obese might be considered "unlikeable," as well as someone with a criminal record, someone on welfare, or someone of a religious or racial minority. But in these reform states, a client's "likeability" is not the primary part of the equation; instead, lawyers focus on their ability to prove the wrongdoing of the defendant. Thus, in reform states, a client's perceived moral failings or status characteristics become much less important to lawyers' decisions about what cases to accept when the other components of a case are good.

The implication of my findings - that new groups of people may gain access to the civil justice system - is potentially broad and significant. These might include people with unappealing personalities (e.g., micromanagers, the rude, or obnoxious) as well as those with low status or demographic characteristics (e.g., former criminals, drug users, welfare recipients, or racial minorities). Even if these cases are lost, the fact that tort reform may possibly open the courthouse door for some, even as it closes the door for others, is an important finding that should not be overlooked.

Another implication, which remains to be tested, relates to the making of tort law itself. Lawyers in reform states, who are taking fewer risks on cases, may also be less likely to accept risky cases which push the boundaries of current consumer protections. Historically, some of the most significant advancements in tort law have emerged from previously untested cases, including determinations about which parties can be held liable for injuries, under what conditions product manufacturers or doctors can be held liable, statutes of limitations, and categories of damages that are recoverable. And important consumer protections, such as warning labels, safe product designs, car crash tests, and medical drug testing, also result from these kinds of cases that pushed the boundaries of current tort laws. Indeed, lawyers' past risks on cases concerning silicone breast implants, tobacco, asbestos, flammable pajamas, prescription drugs, and vaccines have all led to major expansions of consumer protections and other advancements in tort law (Bogus 2001; Burke 2002; Dobbs 2000; Koenig and Rustad 2001; Vetri 1998). If lawyers in tort reform states are less likely to take on these kinds of risky, precedent-setting cases, the development of new consumer protections may be restricted. This will affect everyone, not just consumers in tort reform states. 
My findings suggest a number of interesting questions that, while beyond the scope of this article, are worthy of further research. For example, I did my study in locations where media campaigns and legal changes were closely aligned, and it is thus difficult to interpret whether it was the media campaigns, the changes in tort law, or their combination that shaped lawyers' decision making process. Future research thus might examine states in which changes in tort law are not accompanied by media campaigns to better evaluate the relationship between cultural and legal changes. Another question this study raises is whether there are differences between the kinds of plaintiffs that appear in the courts before and after tort reform. If lawyers actually screen cases the way they say they screen cases in the current study, there should be a measurable increase in the proportion of "unlikeable" plaintiffs in the courts after tort reform.

While my findings demonstrate that context matters in lawyers' case selection, tort reform may not be the only cause of the differences in how lawyers evaluate cases. Massachusetts and Pennsylvania are different from Colorado and Texas politically, culturally, and in other ways besides tort reform. Moreover, I only have concrete data on the post-reform period (aside from lawyers' recollections of how they evaluated cases prereform). Future studies should attempt to disentangle these cultural and temporal issues.

Yet, as I have argued elsewhere (Trautner 2009), there are important merits in studying lawyer decision making and the case evaluation process in a comparative research design. Previous studies of plaintiff's lawyers or case selection have focused on lawyers in only one city or state (e.g., Daniels and Martin 1999, 2000, 2001; Kritzer 1997a, b, 2004; Parikh 2001; Van Hoy 1999), and have demonstrated that lawyers are highly selective about the cases they accept, choosing only those they believe have a good chance of winning. But as I have shown in this study, lawyers' definitions of what makes a case winnable varies dramatically by legal environment. These nuances in how lawyers evaluate cases can dramatically impact the types of people who gain access to the civil justice system and the types of cases that are brought before juries, which in turn have the potential to affect consumer protections more generally.

Acknowledgments This research was supported by a Dissertation Improvement Grant from the National Science Foundation (SES \#0451762). I would like to thank the Editor and anonymous reviewers for their helpful suggestions. I am also grateful to Erin Hatton, Robert Wagmiller, Brayden King, Debra Street, Ellen Berrey, Robert Granfield, Calvin Morrill, Sarah Soule, and Ronald Breiger for comments on earlier drafts of this article.

\section{References}

Abel, Richard L. 1987. The real tort crisis: Too few claims. Ohio State Law Journal 48(2): 443-467.

American Tort Reform Association (ATRA). 2003. Bringing justice to judicial hellholes. http://www.atra.org/ reports/hellholes/. Accessed 10 June 2004.

American Tort Reform Association (ATRA). 2004. Tort reform record. http://www.atra.org/files.cgi/ 7802_Record6-04.pdf. Accessed 15 July 2004.

Avraham, Ronen. 2006. Database of state tort law reforms. Law and economics research paper series no. 0608. 2nd ed. Chicago: Northwestern University School of Law.

Baker, Tom. 2005. The medical malpractice myth. Chicago: University of Chicago Press.

Bogus, Carl T. 2001. Why lawsuits are good for America: Disciplined democracy, big business, and the common law. New York: New York University Press.

Boynton, Paul D. 1999. Study: Massachusetts near the bottom in civil verdicts. Massachusetts Lawyers Weekly, December 13. http://www.masslaw.com/reprints/breakstone121399.htm. Accessed online 15 July 2004.

Burke, Thomas H. 2002. Lawyers, lawsuits, and legal rights: The battle over litigation in American society. Berkeley: University of California Press. 
Carroll, James K., Linda A. Klein, and Steven B. Lesser. 2004. Report on contingent fees in medical malpractice litigation. Report prepared for the American Bar Association Tort Trial \& Insurance Practice Section. Retrieved February 2, 2006 (https://www.cttriallawyers.org/pdfs/reports_7.pdf).

Cohen, Thomas H., and Steven K. Smith. 2004. Civil trial cases and verdicts in large counties. Bureau of Justice Statistics Bulletin, NCJ 203098. Washington, DC: U.S. Department of Justice.

Crane, Mark. 1988. Lawyers don’t take every case. National Law Journal 10(20): 1-34.

Daniels, Stephen, and Joanne Martin. 1999. 'It's Darwinism—-survival of the fittest:' How markets and reputations shape the ways in which plaintiffs' lawyers obtain clients. Law \& Policy 21(4): 377-399.

Daniels, Stephen, and Joanne Martin. 2000. 'The impact that it has had is between people's ears': Tort reform, mass culture, and plaintiffs' lawyers. DePaul Law Review 50(2): 453-496.

Daniels, Stephen, and Joanne Martin. 2001. 'We live on the edge of extinction all the time:' Entrepreneurs, innovation and the plaintiffs' bar in the wake of tort reform. In Legal professions: Work, structure, and organization, ed. Jerry Van Hoy, 149-180. New York: JAI Press.

Daniels, Stephen, and Joanne Martin. 2004. The strange success of tort reform. Emory Law Journal 53(3): $1225-1262$.

Dobbs, Dan B. 2000. The law of torts. St. Paul: West Group.

Edelman, Lauren B. 1990. Legal environments and organizational governance: The expansion of due process in the American workplace. The American Journal of Sociology 95(6): 1401-1440.

Edelman, Lauren B. 1992. Legal ambiguity and symbolic structures: Organizational mediation of law. The American Journal of Sociology 97(6): 1531-1576.

Edelman, Lauren B., and Mark Suchman. 1997. The legal environments of organizations. Annual Review of Sociology 23: 479-515.

Edelman, Lauren B., and Mark Suchman. 1999. When the 'haves' hold court: Speculations on the organizational internalization of law. Law \& Society Review 33(4): 941-991.

Engel, David M. 1984. The oven bird's song: Insiders, outsiders, and personal injuries in an American community. Law \& Society Review 18(4): 551-582.

Ewick, Patricia, and Susan S. Silbey. 1998. The common place of law: Stories from everyday life. Chicago: University of Chicago Press.

Finley, Lucinda. 1997. Female trouble: The implications of tort reform for women. Tennessee Law Review 64 (3): $847-880$.

Finley, Lucinda. 2004. The hidden victims of tort reform: Women, children, and the elderly. Emory Law Journal 53(3): 1263-1314.

Frohmann, Lisa. 1991. Discrediting victims' allegations of sexual assault: Prosecutorial accounts of case rejections. Social Problems 38(2): 213-226.

Frohmann, Lisa. 1997. Convictability and discordant locales: Reproducing race, class, and gender ideologies in prosecutorial decisionmaking. Law \& Society Review 31(3): 531-555.

Granfield, Robert. 2001. Regulating corporate misconduct: The social functions of tort law. Suffolk University Law Review 35(3): 491-511.

Granovetter, Mark. 1985. Economic action and social structure: The problem of embeddedness. The American Journal of Sociology 91: 481-510.

Greene, Edith. 1990. Media effects on jurors. Law and Human Behavior 14(5): 439-450.

Haltom, William, and Michael McCann. 2004. Distorting the law: Politics, media, and the litigation crisis. Chicago: University of Chicago Press.

Harris Interactive. 2004. State liability systems ranking study: Final report. Conducted for the U.S. Chamber of Commerce and the U.S. Chamber Institute for Legal Reform. Released March 8.

Hayes, Hannah. 2005. Women winners of the plaintiffs' bar. Perspectives: A magazine for and about women lawyers, volume 13, no 4. Published by the American Bar Association Commission on Women in the Profession.

Huber, Peter W. 1990. Liability: The legal revolution and its consequences. New York: Basic Books.

Kasindorf, Martin. 2004. Robin Hood is alive in court, say those seeking lawsuit limits. USA Today. March 7.

Kessler, Daniel, and Mark McClellan. 1996. Do doctors practice defensive medicine? Quarterly Journal of Economics 111: 353-390.

Koenig, Thomas H., and Michael L. Rustad. 2001. In Defense of tort law. New York: New York University Press.

Krippner, Greta R., and Anthony S. Alvarez. 2007. Embeddedness and the intellectual projects of economic sociology. Annual Review of Sociology 33: 219-240.

Kritzer, Herbert. 1996. Rhetoric and reality...uses and abuses...contingencies and certainties: The American contingent fee in operation. Working Paper 12-2, Disputes Processing Research Program, Institute for Legal Studies, University of Wisconsin Law School.

Kritzer, Herbert. 1997a. Contingency fee lawyers as gatekeepers in the American civil justice system. Judicature 81(1): 22-29. 
Kritzer, Herbert. 1997b. Holding back the floodtide: The role of contingent fee lawyers. Wisconsin Lawyer 70 (3): $10-13.62,64$.

Kritzer, Herbert. 2004. Risks, reputations, and rewards: Contingency fee legal practice in the United States. Stanford: Stanford University Press.

Kritzer, Herbert M., and Jayanth K. Krishnan. 1999. Lawyers seeking clients, clients seeking lawyers: Sources of contingency fee cases and their implications for case handling. Law \& Policy 21: 347-375.

Kritzer, Herbert M., and Frances Kahn Zemans. 1993. Local legal culture and the control of litigation. Law \& Society Review 27(3): 535-557.

Lofquist, William S. 2002. Closing the courthouse door: Constructing undeservingness in the tort and habeas corpus reform movements. Sociological Spectrum 22(2): 191-223.

Loftus, Elizabeth. 1979. Insurance advertising and jury awards. American Bar Association Journal 65(1): 68-70.

LoPucki, Lynn M. 1996. Legal culture, legal strategy, and the law in lawyers' heads. Northwestern University Law Review 90(4): 1498-1556.

Martin, Joanne, and Stephen Daniels. 1997. Access denied: Tort reform is closing the courthouse door. Trial 33(7): 26-31.

Michelson, Ethan. 2006. The practice of law as an obstacle to justice: Chinese lawyers at work. Law \& Society Review 40(1): 1-38.

Olson, Walter K. 1991. The litigation explosion: What happened when America unleashed the lawsuit. New York: Truman Talley Books.

Parikh, Sara. 2001. Professionalism and its discontents: A study of social networks in the plaintiff's personal injury bar. Doctoral Dissertation, Department of Sociology, University of Illinois at Chicago.

Pescosolido, Bernice. 1992. Beyond rational choice: The social dynamics of how people seek help. The American Journal of Sociology 97(4): 1096-1138.

Sandefur, Rebecca. 2008. Access to civil justice and race, class, and gender inequality. Annual Review of Sociology 34: 339-358.

Sarat, Austin. 1977. Studying American legal culture: An assessment of survey evidence. Law \& Society Review 11(3): 427-488.

Sharkey, Catherine M. 2005. Unintended consequences of medical malpractice damage caps. New York University Law Review 80(2): 391-512.

Stanko, Elizabeth Anne. 1981-82. The impact of victim assessment on prosecutors' screening decisions: The case of the New York county district attorney's office.” Law \& Society Review 16, no. 2: 225-239.

Sudnow, David. 1965. Normal crimes: Sociological features of the penal code in a public defender office. Social Problems 12(3): 255-276.

Sullivan, Teresa, Elizabeth Warren, and Jay Lawrence Westbrook. 1994. The persistence of local legal culture: Twenty years of evidence from the federal bankruptcy courts. Harvard Journal of Law and Public Policy 17(3): 801-865.

Sutton, John R., Frank R. Dobbin, John W. Meyer, and W.Richard Scott. 1994. The legalization of the workplace. The American Journal of Sociology 99(4): 944-971.

Swartz, Mimi. 2005. Hurt? Injured? Need a lawyer? Too bad! Texas Monthly 33(11): 165-169. 218-234, $254-258$.

Tooher, Nora Lockwood. 2005. Merck scores victory In N.J. Vioxx Trial. Lawyers Weekly USA. November 21.

Trautner, Mary Nell. 2009. Personal responsibility v. corporate liability: How personal injury lawyers screen cases in an era of tort reform. Sociology of Crime, Law and Deviance 12: 203-230.

Van Hoy, Jerry. 1999. Markets and contingency: How client markets influence the work of plaintiffs' personal injury lawyers. International Journal of the Legal Profession 6(3): 345-366.

Vetri, Dominick. 1998. Tort law and practice. New York: Matthew Bender \& Co.

Vidmar, Neil. 1998. Maps, gaps, sociolegal scholarship, and the tort reform debate. In Social science, social policy, and the law, ed. P. Ewick, R.A. Kagan, and A. Sarat, 170-209. New York: Sage.

Zegart, Dan. 2004. The right wing's drive for 'tort reform'.The Nation, October 25. http://www.thenation. com/doc/20041025/zegart. Accessed 1 January.

Zukin, Sharon, and Paul Dimaggio (eds.). 1990. Structures of capital: The social organization of the economy. New York: Cambridge University Press.

Mary Nell Trautner is an assistant professor of sociology at the University at Buffalo, SUNY. She studies law, labor and organizations, and gender and the body. 